\title{
INTERFERENCIA DEL INHIBIDOR LÚPICO EN LA PRUEBA DE PROTROMBINA: EFECTO DE LA VARIABILIDAD DE LOS REACTIVOS. INFORME DE UN CASO.
}

\section{Quirós Quirós, William}

Laboratorio Especializado del Servicio de Hematología. Hospital Dr. Calderón Guardia, San José, Costa Rica.

\begin{abstract}
Resumen: El anticoagulante lúpico ejerce un efecto inhibitorio sobre las pruebas de coagulación dependientes de fosfolípidos, especialmente sobre el TTP, pero también sobre el TP. Dependiendo del tipo de reactivos, de su concentración, de la técnica de medición y de la heterogeneidad de los anticuerpos, podemos obtener discrepancias en la interpretación de un inhibidor. Presentamos el caso de un paciente hematooncológico que desarrolló un inhibidor tipo lúpico con discrepancias en los tiempos de coagulación que afectaron el manejo clínico del paciente.
\end{abstract}

Palabras clave: anticoagulante lúpico, inhibidores de coagulación, antifosfolípidos, tiempo de protrombina. Fuente: MESH.

Revista electrónica publicada por el Departamento de Farmacología de la Escuela de Medicina de la Universidad de Costa Rica, 2060 San José, Costa Rica. ${ }^{\circledR}$ All rights reserved. Licensed under a Creative Commons Unported License. 


\section{INTERFERENCE OF LUPUS INHIBITORS \\ IN PROTHROMBIN TIME ASSAYS: EFFECT OF REAGENT VARIABILITY. A CASE REPORT.}

Abstract: Lupus anticoagulant exerts an inhibitory effect on phospholipid-dependent coagulation tests, especially on TTP but also on PT. Depending on the type of reagents, its concentration, the technique of measurement and the heterogeneity of the antibodies, we can obtain discrepancies in the interpretation of the inhibitor. We present the case of a hemato-oncologic patient who developed a lupus inhibitor with the discrepancies in coagulation times that affected the clinical management of the patient.

Key words: lupus anticoagulant, antiphospholipids, coagulation inhibitors, prothrombin time. Source: MESH.

\section{INTRODUCTION}

According the cell-based model of coagulation, the phospholipids constitute an essential part to the fibrin formation [1,2]. Sometimes these phospholipids, part of them, or the complex mounding with other proteins; are target for the antibodies formation [3-6].

Antiphospholipid antibodies represent a heterogeneous group of immunoglobulins that are linked to cell membrane and phospholipids of the clotting cascade $[7,8]$. They are not associated precisely with bleeding, but rather with an increased risk of thrombosis [9-13].

These antibodies appear in various clinical processes, particularly in patients with Systemic Lupus Erythematosus (SLE) and some malignancies [14-19]. Occasionally it has also been described antibodies against specific clotting factors in healthy patients. In clinical practice, the best known are Anti-Cardiolipin antibodies (ACA) and the lupus anticoagulant antibodies (AL) [2025]. The immunoglobulins with Lupus Anticoagulant activity exert an inhibitory effect on
Phospholipid-dependent coagulation tests. For a long time it was considered that AL could affect only the partial thromboplastin time (PTT). It is now known that these immunoglobulins also affect the test of prothrombin time (PT), protein $\mathrm{S}$ and protein C [26-32].

Sometimes, is not possible to establish a clear correlation between antiphospholipid activity and inhibitory activity of lupus anticoagulant. Difficulties associated with interpretation, management, correction, and reporting are very wide, particularly by the diversity of providers, variety of methodologies, range of reagents and the amount and type of phospholipids used in each them [33-35].

The phospholipids are asymmetrically distributed in the membrane of the platelets. The distribution of these phospholipids is strictly controlled. Neutral phospholipids are located on the external leaflet and the negatively charged phospholipids in the inner surface, therefore, under normal conditions, phospholipids are just slightly antigenic [36-38]. 
However, if cell damage, injury or activation occurs, the membrane phospholipids are exposed and become targets for the formation of antiphospholipid antibodies (APL) that are considered procoagulants [39-40].

Currently, the evidence is pointed to that the APL join to a complex phospholipids/serum proteins (especially, beta 2 Glico-Proteina-1 and prothrombin) that undergo conformational changes when joins to the anionic phospholipids [41-48].

Prothrombin has been a common antigenic aim for APL, in around $50-90 \%$ of patients with Antiphospholipid Syndrome. This supports the theory that an APL inhibits the prothrombinasethrombin complex interaction and that the APL antibody is directed against the phospholipid component of this complex. As antiprothrombin antibodies have varied immunologic properties, their clinical significance is still under debate [49, 50].

There are multiples interactions between proteinprotein and protein-phospholipid that makes difficult to validate conclusions about the effect of inhibitors in clinical trials. The interference over traditional coagulation tests (PT and PTT) may be caused by the concentration or type of phospholipids used in different commercial reagents.

\section{CASE REPORT}

A 60-year-old male with diagnosis of primary Lymphoma of spleen, currently with an active hemolytic process is referred to our laboratory for preoperative control prior splenectomy. The patient has no recent studies of coagulation.

Routine tests (PT, PTT and Fibrinogen) were performed for this patient. Samples were taken in vacutainer tubes containing sodium citrate $3.2 \%$ as anticoagulant. The tests were realized with the analyzer CA-500 of Sysmex and the results are detailed in Table No. 1.

Table No. 1. Baseline coagulation assays performed with analyzer Sysmex CA-500.

\begin{tabular}{lll|}
\hline Test & Patient & $\begin{array}{l}\text { Reference } \\
\text { Values }\end{array}$ \\
\hline $\begin{array}{l}\text { Prothrombin Time } \\
\text { Activity } \\
\text { Percentage }\end{array}$ & $53.2 \mathrm{~s}$ & $10.1-11.5 \mathrm{~s}$ \\
\hline $\begin{array}{l}\text { Thromboplastin } \\
\text { Time }\end{array}$ & $38.0 \mathrm{~s}$ & $80-120 \%$ \\
\hline $\begin{array}{l}\text { Fibrinogen } \\
\text { P. }\end{array}$ & $339 \mathrm{mg} / \mathrm{dl}$ & $200-400 \mathrm{mg} / \mathrm{dl}$ \\
\hline
\end{tabular}

$\mathrm{S}=$ segundos, $\mathrm{mg} / \mathrm{dl}=$ miligramos por decilitro .

As the routine coagulation tests showed a significant prolongation of the prothrombin time as the only significant finding, splenectomy was suspended.

The attending physician decides to control results in 12 hours. The prothrombin time prolongation remains the same so it was decided to repeat the tests with a new calibration curve. It is corroborated by manual and automated form, in duplicate and using new reagents of Innovin Sysmex. Both methodologies confirm the outcomes so is discarded a coumarinic effect.

As control, the sample is sent to be analyzed in the ACL TOP 500 coagulometer (Instrumentation laboratory) that reported a discrepancy with the results of our laboratory. All studies were performed before two hours from extraction according to established protocols.

A new sample is processed simultaneously in both laboratories and an aliquot is referred to other laboratory as reference. The coagulation tests of 
reference were carried out with the STACOMPACT coagulometer (Diagnostic STAGO). The results of the three analyzers are shown in table 2 .

Table No. 2. Aliquots processed in three different coagulometers.

\begin{tabular}{|lccc|}
\hline Test & CA-500 & $\begin{array}{c}\text { STA- } \\
\text { COMPACT }\end{array}$ & $\begin{array}{c}\text { ACL TOP } \\
\mathbf{5 0 0}\end{array}$ \\
\hline Prothrombin Time & $43.5 \mathrm{~s}$ & $24.1 \mathrm{~s}$ & $21.9 \mathrm{~s}$ \\
\hline Activity Percentage & $9.7 \%$ & $42 \%$ & $35 \%$ \\
\hline Thromboplastin Time & $42 \mathrm{~s}$ & $75 \mathrm{~s}$ & $79 \mathrm{~s}$ \\
\hline Fibrinogen & $\begin{array}{c}345 \\
\mathrm{mg} / \mathrm{dl}\end{array}$ & $\begin{array}{c}355 \\
\mathrm{mg} / \mathrm{dl}\end{array}$ & $\begin{array}{c}361 \\
\mathrm{mg} / \mathrm{dl}\end{array}$ \\
\hline
\end{tabular}

$\mathrm{S}=$ segundos, $\mathrm{mg} / \mathrm{dl}=$ miligramos por decilitro.

This information suggests the presence of an inhibitor, which is detected in two analyzers (ACL TOP 500 and STA-COMPACT) through prolongation of the partial thromboplastin time and by the analyzer CA-500, through the prolongation of prothrombin time.

According to the recommendations for lupus anticoagulant detection [51], it was decided to make a mixing study 50:50 with normal plasma to distinguish between a factor deficiency or a circulating inhibitor.

The Mixing study do not correct properly the clotting times, so it was decided to perform a neutralization using phosphatidylethanolamine, a neutral phospholipid with which we get a total correction of prothrombin time (graph 1). Based on this result, a lupus inhibitor of high titer would be present.

A lupus anticoagulant investigation test was carried out in our laboratory which was moderately positive. Moreover a silica based clotting time was reported in 99 seconds (34-52 sec.). This result was corroborated with a confirmatory anticoagulant positive test and a positive Rosner Index.

The tests performed confirm us that a Lupus Inhibitor was present in high titer and it was initially detected by the inhibitory effect over prothrombin time.

Graph No. 1. Correction of prothrombin time after Mix 50:50 and neutralization with phospholipids.

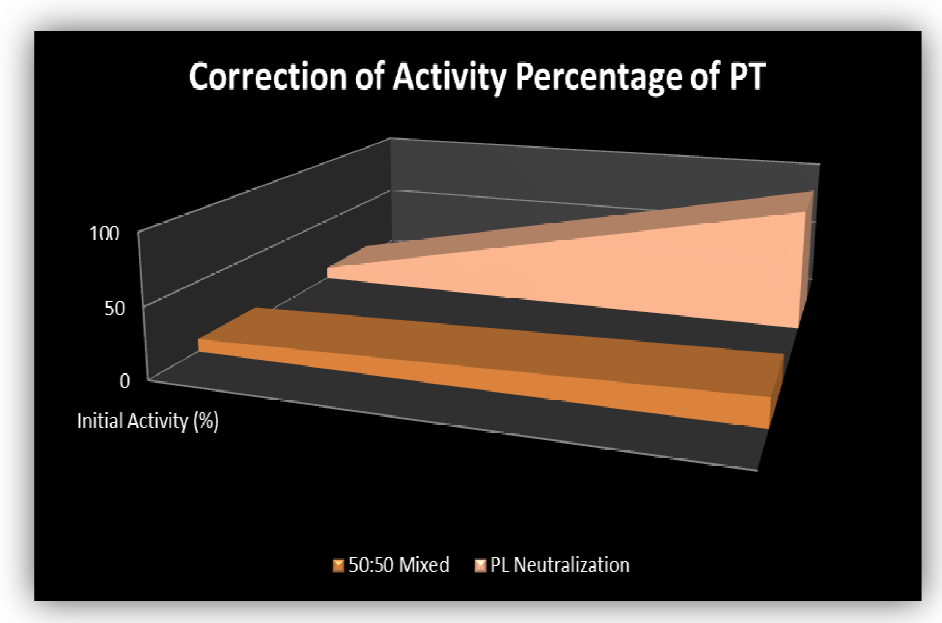

\section{DISCUSSION}

This paper presents the case of a patient studied in the hematology service by a Splenic Lymphoma of marginal zone, with splenomegaly grade III, which develops an antibody in high title that affected the results of their blood clotting tests.

The formation of antibodies with inhibitory effect has been documented in multiple clinical conditions. The Primary spleen lymphoma is a clinical entity associated with presence of Lupus inhibitor [52-54].

The term, lupus anticoagulant inhibitor was first used by Feinstein, and Rapaport in 1972 [55], although Conley and Hartman had described an inhibitor of coagulation in two patients with Systemic Lupus since 1952 [56, 57]. Initially, lupus anticoagulant was defined as "an antibody that prolongs the Activated Cephalin Time (ACT) and 
sometimes, the prothrombin time, but not inactive specifically none of the known coagulation factors" [58].

Currently, different international committees agree to define the lupus anticoagulant as a heterogeneous group of antibodies specific for phospho-lipoproteins or phospholipid components that frequently interfere with standard phospholipid-dependent coagulation tests [59-63]. This definition is subject to many controversies due to the lack of standardization of the different techniques, a wide range of cefalines available commercially, antibodies heterogeneity and differing interpretation strategies [64].

In this case, discrepancies founds in the results were attributed to the amount and kind of phospholipids present in each reagent.

To explain this heterogeneity it should be remembered that the phospholipids are polar compounds having a simple structure with three basic components: a glyceridic portion (diacylglycerol), a phosphodiester group and an alternating or replaceable portion. This alternating portion may be choline, serine, ethanolamine, inositol which identifies each particular phospholipid [65-67].

The phosphodiester group is shared by all the anionic phospholipids and it is responsible for to link the alternating portion to diacylglycerol. For long time, it have been considered the carrier of epitopes to which the anti phospholipids antibodies are binded [68].

Anionic phospholipid as cardiolipin, phosphatidylserine, phosphatidylinositol and phosphatidic acid, exhibit a higher reactivity and ability to bind antiphospholipid antibodies [68].

By other hand, the neutral phospholipids as phosphatidylcholine, phosphatidylethanolamine, sphingomyelin, do not show such reactivity, but they can also join the antiphospholipid antibodies, which may explain the findings in this case.

Neutralization of lupus inhibitor with excess of phospholipids (hexagonal phase phosphatidylethanolamine) allowed us to obtain a correction of the prothrombin time and to confirm the inhibitory effect of lupus on prothrombin time [69].

Based on those results, the patient is treated for several days with $5 \mathrm{mg}$ of prednisolone p.o. without effective response.

The effect that lupus inhibitor could have "In Vivo" in this patient was unknown. Doctors suspended splenectomy and decide chemotherapeutic management using R-CHOP scheme with excellent results, improvement of anemia, and full normalization of clotting times and negativization of lupus anticoagulant. The patient is currently without splenomegaly.

\section{CONCLUSIONS}

There is a great diversity of providers, methodologies and reagents for clotting tests and the amount and type of phospholipids used in each it affect the sensitivity and specificity for detection of lupus anticoagulant [70-72]. Therefore is necessary to follow some guidelines to an appropriate diagnosis of lupus inhibitor.

According to International Guidelines Agreed for Diagnostic of Lupus Inhibitor, it requires a phospholipids-dependent coagulation test altered, a study of mixtures and at least one positive confirmatory test to establish the presence or absence of a lupus inhibitor [73-78].

In our case, three major requirements are present, so it was possible to establish the presence of a high titer lupus inhibitor, whose effect was manifested as a prolongation of prothrombin time. The results obtained using diverse commercial reagents show major discrepancies in clotting 
times between Innovin and Recombiplastin 2G, but similar between Recombiplastin 2G and Neoplastin CI plus. The review of procedures and methodologies, show that these inconsistencies were generated by presence of a lupus inhibitor. The laboratory results gave a viable option for patient management.

It should be remembered that the presence of a lupus inhibitor can alter any phospholipid dependent coagulation test and not necessarily or exclusively the partial thromboplastin time (PTT) as often have seen. However, their determination is useful to identify patients at high risk to develop thrombotic complications, but not to predict treatment outcome or disease prognosis.

It is also important to remember that anti phospholipids antibodies may occur in multiple clinical entities. Discrepancies in coagulation tests may be caused by this type of inhibitors and should be considered, especially, in cases of hematological patients.

\section{CONFLICT OF INTEREST}

The author declare no conflict of interest and declare: no support from any organization for the submitted work; no financial relationships with any organizations that might have an interest in the submitted work in the previous 3 years; no other relationships or activities that could appear to have influenced the submitted work.

\section{BIBLIOGRAPHY}

1. McMichael M. New models of hemostasis. Top Companion Anim Med. 2012; 27(2): 40-45.

2. Versteeg HH, Heemskerk JWM, Levi M, Reitsma PH. New Fundamentals in Hemostasis. Physiol Rev. 2013; 93(1): 327-358.

3. Giannakopoulos B, Krilis SA. The pathogenesis of the antiphospholipid syndrome. N Engl J Med. 2013; 368(11): 1033-1044.

4. Meroni PL, Borghi MO, Raschi E, Tedesco F. Pathogenesis of antiphospholipid syndrome: understanding the antibodies. Nat Rev Rheumatol. 2011; 7(6): 330-339.

5. Levine JS, Branch DW, Rauch J. The antiphospholipid syndrome. N Engl J Med. 2002; 346(10): 752-763.

6. De Groot PG, Derksen RHWM. Pathophysiology of the antiphospholipid syndrome. J Thromb Haemost. 2005; 3(8): 1854-1860.

7. Pierangeli SS, Chen PP, Raschi E, Scurati S, Grossi C, Borghi MO et al. Antiphospholipid antibodies and the antiphospholipid syndrome: pathogenic mechanisms. Semin Thromb Hemost. 2008; 34(3): 236-250.

8. Lim W. Antiphospholipid antibody syndrome. ASH Education Program Book. 2009;2009(1): 233-239.

9. Devreese KM. Antiphospholipid antibodies: evaluation of the thrombotic risk. Thromb Res. 2012; 130: S37-S40.

10. Arnout J. Risk for thrombosis linked to the target antigen of a lupus anticoagulant? J Thromb Haemost. 2004; 2(5): 697-699.

11. Galli M, Barbui T. Antiphospholipid antibodies and thrombosis: strength of association. Hematol J. 2003; 4(3): 180-186.

12. Galli M, Luciani D, Bertolini G, Barbui T. Lupus anticoagulants are stronger risk factors for thrombosis than anticardiolipin antibodies in the antiphospholipid syndrome: A systematic review of the literatura. Blood. 2003; 101(5): 1827-1832.

13. De Groot PG, Lutters B, Derksen RHWM, Lisman T, Meijers JCM, Rosendaal FR. Lupus anticoagulants and the risk of a first episode of deep venous thrombosis. J Thromb Haemost. 2005; 3(9): 19931997.

14. Genvresse I, Lüftner D, Späth-Schwalbe E, Buttgereit F. Prevalence and clinical significance of anticardiolipin and anti-beta2-glycoprotein-I antibodies in patients with non-Hodgkin's lymphoma. Eur J Haematol. 2002; 68(2): 84-90.

15. Tincani A, Taraborelli M, Cattaneo R. Antiphospholipid antibodies and malignancies. Autoimmun Rev. 2010; 9(4): 200-202.

Revista electrónica publicada por el Departamento de Farmacología de la Escuela de Medicina de la Universidad de Costa Rica, 2060 San José, Costa Rica. ${ }^{\circledR}$ All rights reserved. Licensed under a Creative Commons Unported License. 
16. Buller HR, Van Doormaal FF, Van Sluis GL, Kamphuisen PW, Cancer and thrombosis: from molecular mechanisms to clinical presentations. J Thromb Haemost. 2007; 5(1): 246-254.

17. Pham C, Shen Y. Antiphospholipid antibodies ana malignancy. Hematol Oncol Clin North Am. 2008; 22(1): 121-130.

18. Pusterla M, Previtali S, Marziali S, Cortelazzo S, Rossi A, Barbui T et al. Antiphospholipid antibodies in lymphoma: prevalence and clinical significance. Hematol J. 2004; 5(4): 341-346.

19. Gómez-Puerta JA, Cervera R, Espinosa G, Aguiló S, Bucciarelli, S, Ramos-Casals $M$ et al. Antiphospholipid Antibodies Associated with Malignancies: Clinical and Pathological Characteristics of 120 Patients. Semin Arthritis Rheum. 2006; 35(5): 322-332.

20. Zoghlami-Rintelen C, Vormittag R, Sailer T, Lehr S, Quehenberger $\mathrm{P}$, Rumpold $\mathrm{H}$ et al. The presence of IgG antibodies against b2-glycoprotein I predicts the risk of thrombosis in patients with the lupus anticoagulant. J Thromb Haemost. 2005; 3(6): 1160-1165.

21. Petri M. Update on anti-phospholipid antibodies in SLE: The Hopkins' Lupus Cohort. Lupus. 2010; 19: 419-423.

22. Dhir V, Pinto B. Antiphospholipid syndrome: A review. J Mahatma Gandhi Inst Med Sci. 2014; 19(1): 19-27.

23. Galli M. The antiphospholipid triangle. J Thromb Haemost. 2010; 8(2): 234-236.

24. Gómez-Puerta JA, Cervera R. Diagnosis and classification of the antiphospholipid syndrome. J Autoimmun. 2014; 48: 20-25.

25. Sangle NA, Smock KJ. Antiphospholipid Antibody Syndrome, Arch Pathol Lab Med. 2011; 135(9): 1092-1096.

26. Bertolaccini ML, Amengual O, Andreoli L, Atsumi T, Chighizola CB, Forastiero R et al. 14th International Congress on Antiphospholipid Antibodies Task Force. Report on antiphospholipid syndrome laboratory diagnostics and trends. Autoimmun Rev. 2014; 13(9): 917-930.
27. Gardiner C, Hills J, Machin SJ, Cohen H. Diagnosis of antiphospholipid syndrome in routine clinical practice. Lupus. 2013; 22: 18-25.

28. Pengo V, Banzato A, Denas G, Jose SP, Bison E, Hoxha A, Ruffatti A: Correct laboratory approach to APS diagnosis and monitoring. Autoimmun Rev. 2013; 12(8): 832-834.

29. Brand JT, Triplett DA, Rock WA, Bovill EG, Arkin CF, Effect of Lupus Anticoagulants on the Activated Partial Thromboplastin Time. CAP Laboratory Improvement Program. Arch Pathol Lab Med. 1991; 115(2): 109-114.

30. Lollar P. Pathogenic antibodies to coagulation factors. Part II. Fibrinogen, prothrombin, thrombin, factor V, factor XI, factor XII,factor XIII, the protein C system and von Willebrand factor. J Thromb Haemost. 2005; 3(7): 1385-1391.

31. Della Valle P, Crippa ., Garlando AM, Pattarini E, Safa O, D'Angelo S, D'Angelo A. Interference of lupus anticoagulants in prothrombin time assays: implications for selection of adequate methods to optimize the management of thrombosis in antiphospholipid-antibody síndrome. Haematologica. 1999; 84(12): 1065-1074.

32. Tripodi A. Laboratory Testing for Lupus Anticoagulants: A Review of Issues Affecting Results. Clinical Chemistry. 2007; 53(9): 16291635.

33. Shetty S, Ghosh K, Mohanty D. Comparison of four commercially available activated partial thromboplastin time reagents using a semiautomated coagulometer. Blood Coagul Fibrinolysis. 2003; 14(5):493-497.

34. Detarsio GA, Soler C, Paredes J, Milani AC, Ordi-Ros J, Lupus Anticoagulant: Sensitivity of 19 commercial activated partial thromboplastin time reagents. Acta Bioquím Clín Latinoam. 2007; 41(4): 533-539.

35. Testa S, Morstabilini G, Fattorini A, Galli L, Denti N, D'Angelo A. Discrepant sensitivity of thromboplastin reagents to clotting factor levels explored by the prothrombin time in patients on stable oral anticoagulant treatment: impact on the international normalized ratio system. Haematologica. 2002; 87(12): 1265-1273. 
36. Yamaji-Hasegawa A, Tsujimoto M. Asymmetric distribution of phospholipids in biomembranes. Biol Pharm Bull. 2006; 29(8):1547-1553.

37. Zwaal R, Schroit AJ. Pathophysiologic Implications of Membrane Phospholipid Asymmetry in Blood Cells. Blood. 1997; 89(4): 1121-1132.

38. Deeba F, Tahseen HN, Sharad KS, Ahmad N, Akhtar S, Saleemuddin $M$ et al. Phospholipid diversity: correlation with membrane-membrane fusion events. Biochim Biophys Acta. 2005; 1669(2): 170181.

39. Smith, SA. The cell-based model of coagulation. J Vet Emerg Crit Care. 2009; 19(1): 3-10.

40. Caron P, Moll MS, Antiphospholipid Antibodies. Circulation. 2005; 112: 39-44

41. Agar C, van Os GM, Morgelin M, et al. Beta2glycoprotein I can exist in 2 conformations: implications for our understanding of the antiphospholipid syndrome. Blood. 2010; 116(8): 1336-43.

42. Ninivaggi $M$, Kelchtermans $H$, Lindhout $T$, de Laat HB, Conformation of beta- 2 glycoprotein I and its effect on coagulation. Thrombosis Research. 2012; 130: 33-36.

43. De Laat HB, Derksen RHWM, Urbanus RT, Roest M, de Groot PG. B2- glycoprotein I dependent lupus anticoagulant highly correlates with thrombosis in the antiphospholipid syndrome. Blood. 2004; 104(12): 3598-3602.

44. Roubey R. Autoantibodies to Phospholipid-Binding Plasma Proteins: A New View of Lupus Anticoagulants and Other "Antiphospholipid" Autoantibodies. Blood. 1994; 84, 2854-2867.

45. Mcneil P, Simpsont R, Chesterman C, Krilis S. Antiphospholipid antibodies are directed against a complex antigen that includes a lipid-binding inhibitor of coagulation: Glycoprotein I. Proc. Natd. Acad Sci. 1990; 87(11): 4120-4124.

46. Meijide H, Sciascia S, Sanna G, Khamashta MA, Bertolaccini ML. The clinical relevance of IgA anticardiolipin and IgA anti- $\beta 2$ glycoprotein I antiphospholipid antibodies. A systematic review. Autoimmun Rev. 2013; 12(3): 421-425.
47. Forastiero R, Martinuzzo M, Pombo G, Puente D, Rossi A, Celebrin L et al. A prospective study of antibodies to b2-glycoprotein I and prothrombin, and risk of thrombosis. J Thromb Haemost. 2005; 3(6): 1231-1238.

48. De Groot PG, Meijers JCM, B2-Glycoprotein I: evolution, structure and function. J Thromb Haemost. 2011; 9(7): 1275-1284.

49. Sciascia S, Sanna G, Murru V, Roccatello D, Khamashta MA, Bertolaccini ML. Anti-prothrombin (aPT) and antiphosphatidylserine/prothrombin (aPS/PT) antibodies and the risk of thrombosis in the antiphospholipid syndrome. A systematic review. Thromb Haemost. 2014; 111: 354-64.

50. Bevers EM, Galli M, Barbui T, Comfurius P, Zwaal RF. Lupus anticoagulant IgG's (LA) are not directed to phospholipids only, but to a complex of lipid-bound human prothrombin. Thromb Haemost. 1991; 66(6): 629-632.

51. Pengo V, Tripodi A, Reber G, Rand JH, Ortel TL, Galli $M$, et al. Update of the guidelines for lupus anticoagulant detection. Subcommittee on Lupus Anticoagulant/Antiphospholipid Antibody of the Scientific and Standar disation Committee of the International Society on Thrombosis and Haemostasis. J Thromb Haemost. 2009; 7(10): 173740.

52. Franco V, Florena A, Iannitto E. Splenic marginal zone lymphoma. Blood. 2003; 101(7): 2464-2472.

53. Wani NA, Parray FQ. Primary lymphoma of the spleen: an experience with seven patients. Int Surg. 2005; 90(5): 279- 283.

54. Matutes E, Oscier D, Montalban C, Berger F, CalletBauchu E, Dogan A et al. Splenic marginal zone lymphoma proposals for a revision of diagnostic, staging and therapeutic criteria. Leukemia. 2008; 22(3): 487-95.

55. Feinstein DI, Rapaport SI. Acquired inhibitors of blood coagulation. Prog. Hemost. Thromb. 1972; 1: 75-95.

56. Conley CL, Hartmann RC. A hemorrhagic disorder caused by circulating anticoagulant in patients with disseminated lupus erythematosus. Clin Invest. 1952; 31: 621-622.

Revista electrónica publicada por el Departamento de Farmacología de la Escuela de Medicina de la Universidad de Costa Rica, 2060 San José, Costa Rica. ${ }^{\circledR}$ All rights reserved. Licensed under a Creative Commons Unported License. 
57. Conley CL. Disorders of the blood in disseminated lupus erythematosus. Am J Med. 1952; 13: 1-2.

58. Conte A, Cadoudal N, Siguret V. Síndrome de anticuerpos antifosfolípidos., Acta Bioquím Clín Latinoam. 2008; 42: 271-278.

59. Merashli M, Hassan M, Noureldine A, Uthman I, Khamashta M. Antiphospholipid syndrome: an update. Eur J Clin Invest. 2015; 45 (6): 653-662.

60. Penmetsa GP, Rodgers GM, Smock KJ. Avoiding errors in the laboratory evaluation of potent lupus anticoagulants. Am J Hematol. 2010; 85(4): 272-274.

61. Ledford-Kraemer M., et al. H60-A: Laboratory Testing for the Lupus Anticoagulant; Approved Guideline. Clinical and Laboratory Standards Institute. 2014 Apr; 34(6): 1-93.

62. Moore GW. Recent Guidelines and Recommendations for Laboratory Detection of Lupus Anticoagulants. Semin Thromb Hemost. 2014; 40(2): 163-171.

63. Pengo V, Tripodi A, Reber G, Rand JH, Ortel TL, Galli $\mathrm{M}$ et al. Subcommittee on Lupus Anticoagulant/Antiphospholipid Antibody of the Scientific and Standardisation Committee of the International Society on Thrombosis and Haemostasis. Update of the guidelines for lupus anticoagulantdetection. J Thromb Haemost. 2009; 7(10): 1737-1740.

64. Moore GW. Current Controversies in Lupus Anticoagulant Detection. Antibodies. 2016; 5(4): 22.

65. Urbanus RT, Derksen RH, de Groot PG. Current insight into diagnostics and pathophysiology of the antiphospolipid syndrome. Blood Rev. 2008; 22(2): 93-105.

66. Giannakopoulos B, Krilis SA. The Pathogenesis of the Antiphospholipid Syndrome. N Engl J Med. 2013; 368(11): 1033-1044.

67. Contreras MA. Inmunopatogenia del Síndrome Antifosfolípido. Rev Chil Reumatol. 2009; 25(4): 149-155.

68. Jones and Bartlett Learnings. LLC. Phospholipids and Membrane Structure. Última Consulta 20 de diciembre 2016. Disponible en:

http://samples.jbpub.com/9781449637514/57748_ CH04_117_rev2.pdf.
69. Triplett DA, Barna LK, Unger GA. A Hexagonal (II) phase Phospholipid neutralization Assay for Lupus Anticoagulant Identification. Thromb Haemost. 1993; 70(5): 787-793.

70. Lawrie AS, Mackie IJ, Purdy G, Machin SJ. The sensitivity and specificity of commercial reagents for the detection of lupus anticoagulant show marked differences in performance between photooptical and mechanical coagulometers. Thromb. Haemost. 1999; 81(5): 758-762.

71. Wong RC, Favaloro EJ, Pollock W. A multi-centre evaluation of the intra-assay and inter-assay variation of commercial and in-house anticardiolipin antibody assays. Pathology. 2004; 36(2): 182-192.

72. Roberts JM, Macara LM, Chalmers EA, Smith GC. Inter-assay variation in antiphospholipid antibodies testing. BJOG. Int J Gynaecol Obstet. 2002; 109(3): 348-349.

73. Keeling D, Mackie I, Moore GW, Greer I, Greaves M. Guidelines on the investigation and management of antiphospholipid syndrome. Br J Haematol. 2012; 157(1): 47-58.

74. Swadzba J, Iwaniec T, Pulka M, de Laat B, de Groot PG, Musial J. Lupus anticoagulant: performance of the tests as recommended by the latest ISTH guidelines. J Thromb Haemost. 2011; 9(9): 17761783.

75. Tripodi A. Testing for lupus anticoagulants: all that a clinician should know. Lupus. 2009; 18: 291-298.

76. Pengo V, Tripodi A, Reber G, Rand JH, Ortel TL, Galli M, de Groot PG. Update of the guidelines for lupus anticoagulant detection. J Thromb Haemost. 2009; 7(10): 1737-1740.

77. Pengo V, Biasiolo A, Pegoraro C, Cucchini U, Noventa F, Iliceto S. Antibody profiles for the diagnosis of antiphospholipid syndrome. Thromb Haemost. 2005; 93(6): 1147-52.

78. Wong R, Adelstein S, Gillis D, Favaloro E. Development of Consensus Guidelines for Anticardiolipin and Lupus Anticoagulant Testing. Seminars in Thrombosis and Hemostasis. 2005; 31(1): 39-48.

\section{CORRESPONDENCIA:}

Quirós Quirós, William.

Correo: wqquiros@gmail.com 